\title{
MEMBANGUN KEUNGGULAN BERSAING INDUSTRI KECIL GULA MERAH TEBU (IKGMT) : Kiat Bersaing di Pasar Ekspor
}

\author{
Suparyadi \\ Fakultas Ekonomi \\ Universitas Islam Kadiri Jawa Timur
}

\begin{abstract}
Abstrak
Salah satu arah kebijakan pembangunan nasional di bidang ekonomi yang didasarkan pada visi dan misi GBHN 1999-2004 adalah "memberdayakan pengusaha kecil, menengah dan koperasi, agar efisien, produktif dan berdaya saing dengan menciptakan iklim berusaha yang kondusif dan peluang usaha yang seluas-luasnya, pemberian bantuan fasilitas dari negara antara lain dalam bentuk pendidikan dan pelatihan, teknologi, permodalan". Kalimat ini begitu menyejukkan dan memberi harapan nan indah bagi para pengusaha kecil dan menengah bahwa mereka akan segera terbebas dari lilitan masalah kehidupan ekonomi yang serba kecil, terpuruk dan berada di ambang kebangkrutan, bahkan sebagian di antara mereka sudah ambruk dan tidak bisa bangkit lagi.

Masa berlakunya ketetapan MPR, NOMOR IV/MPR/1999 Tanggal 21 Oktober 1999 tentang GBHN 1999-2004 hampir habis, tetapi kondisi IKGMT di Kabupaten Kediri hampir tidak berubah, kecuali jumlahnya yang makin menyusut yaitu ketika tahun 2000 masih sebanyak 415 unit, kini tingal 38 persen. Nasib IKGMT di Kabupaten Kediri seperti anak tiri dan mungkin hal ini juga dialami oleh UKM di seluruh negeri tercinta ini. Iklim usaha tetap tidak kondusif, bantuan pendidikan dan pelatihan kurang dari 2 persen kebutuhan. Bantuan permodalan? Klasik, mereka terhadang persyaratan teknis perbankan.

Makalah ini dimaksudkan untuk memberikan sumbangan pemikiran pemecahan masalah dari aspek teknis bisnis, terutama bagaimana membangun keunggulan bersaing IKGMT agar mereka eksis dalam persaingan yang makin ketat. Namun ini semua tidak akan bermakna apa-apa tanpa dukungan pihak-pihak terkait, termasuk dunia perbankan, terutama peran aktif pemerintah selaku pemegang otoritas kebijakan publik.
\end{abstract}

Key Words : Kreativitas, Inovasi, Konsistensi

\section{PENDAHULUAN}

Kotler dan Amstrong (1997) menawarkan 5 (lima) konsep alternatif yang melandasi aktivitas pemasaran organisasi, antara lain adalah konsep pemasaran yang berwawasan pelanggan. Dalam konsep pemasaran berwawasan pelanggan ini, persepektif pemikiran manajemen dimulai dari luar menuju ke dalam, maksudnya adalah bahwa manajemen dalam menyusun program pemasaran memulainya dengan terlebih dulu memusatkan perhatian atas fokus pada kebutuhan pelanggan, kemudian mengkoordinasikan semua aktivitas pemasaran guna mempengaruhi pelanggan dan memperoleh laba dengan menciptakan hubungan jangka panjang dengan pelanggan berdasarkan nilai bagi kepuasan pelanggan.

Suatu survei yang dilakukan oleh majalah SWA yang bekerja sama dengan lembaga penelitian Marketing Research Specialist (MARS) 
dan Mark-Plus, pada tahun 1993, menyimpulkan bahwa semakin banyak perusahaan Indonesia yang serius menjalankan program-program customer satisfaction (CS). Semua perusahaan yang menjadi responden dalam survei menyatakan bahwa mendapat hasil yang memuaskan, penjualan meningkat dan mereka berhasil memperbanyak jumlah pelanggan yang loyal (Djatmiko, 2001). Hasil survei yang lain menunjukkan bahwa untuk kategori obat sakit kepala, Puyer Bintang Toejoe yang usianya hampir mencapai kepala enam, menduduki peringkat teratas dalam memuaskan pelanggan, mengalahkan produk-produk merek relatif baru seperti Paramex, Panadol atau Bodrex. Keberhasilan Puyer Bintang Toejoe mengalahkan pesaing-pesaingnya dalam memuaskan pelanggan karena adanya 2 (dua) faktor utama yaitu kekuatan merek dan pelanggan yang sangat loyal (Yuswohady, 2001). Kekuatan merek terletak pada persepsi kualitas yang tinggi yang terbentuk oleh kokohnya beberapa atribut kualitas seperti kemanjuran dan khasiat serta keamanan produk yang telah teruji selama puluhan tahun. Nampaknya pembuktian atas penawaran kualitas produk yang berlangsung dalam rentang waktu yang sangat panjang itu dan mampu memberikan pengalaman yang meyakinkan pada pelanggan, telah menciptakan pelanggan yang sangat loyal.

Teciptanya hubungan jangka panjang antara perusahaan dengan pelanggan seperti dikemukakan oleh Kotler dan Amstrong (1997) dan Yuswohady (2001) di atas, memungkinkan terjadinya proses saling mengenal dan kesepahaman antara perusahaan dengan pelanggan. Perusahaan dan pelanggan saling memahami standar nilai yang hendak dipertukarkan yaitu perusahaan makin memahami level dan karakteristik atau spesifikasi ekspektasi pelanggan, sedangkan pelanggan makin memahami level dan kinerja produk. Dengan demikian, pada gilirannya akan tercipta suatu kondisi di mana persepsi produsen terhadap ekspektasi pelanggan mendekati atau sama dengan ekspektasi pelanggan yang sesungguhnya. Kondisi inilah yang menjadikan pelanggan puas, karena ekspektasinya dapat dipenuhi oleh produsen.

Kepuasan pelanggan pada dasarnya merupakan fungsi dari ekspektasi dan persepsi terhadap kinerja suatu merek setelah pelanggan menggunakan atau mendapatkan pelayanan, sedangkan loyalitas merupakan fungsi dari kepuasan pelanggan dan faktor lain. Dengan kata lain, pelanggan yang puas cenderung loyal, namun loyalitasnya tidak mencapai 100 persen karena adanya faktor lain yang berpengaruh (Agung, 2001). Diyakini oleh Agung (2001) bahwa loyalitas inilah yang sesungguhnya bertanggung jawab terhadap tingkat profitabilitas, karena pelanggan yang loyal cenderung membeli lebih banyak dan tidak peka terhadap harga. Goni (2001) menyatakan bahwa berbagai penelitian empiris mengungkapkan bahwa tidak ada korelasi positif antara meningkatnya nilai kepuasan dan 
keutungan perusahaan, tingkat kepuasan yang tinggi dari konsumen tidak selamanya diikuti dengan meningkatnya penjualan dan keuntungan. Kedua pendapat di atas pada dasarnya menyatakan bahwa kepuasan bukan merupakan satu-satunya faktor yang dapat mempengaruhi penjualan dan laba perusahaan. Agung (2001) mengidentifikasi adanya faktor lain yang berpengaruh yaitu switching barrier dan personal loyality, sedangkan Goni (2001) mengemukakan bahwa penyebabnya adalah implementasi dari marketing mix serta penentuan strategi segmenting dan positioning.

Volume penjualan, laba dan juga pangsa pasar, merupakan elemen-elemen dari kinerja pemasaran perusahaan yang perwujudannya dipengaruhi oleh banyak faktor. Hal-hal yang dikemukakan oleh para praktisi di atas hanyalah sebagian saja dari begitu banyak faktor yang berpengaruh terhadap kinerja pemasaran, misalnya faktor-faktor ekonomi, teknologi, kekuatan politik-hukum, kekuatan sosial budaya, peranan pemasok dan perantara, preferensi pasar, faktor-faktor internal perusahaan serta faktor pesaing dan persaingan.

Tulisan ini akan menjadikan hasil penelitian Suparyadi (2003) tentang industri kecil gula merah di Kabupaten Kediri sebagai contoh dalam membahas bagaimana membangun keunggulan bersaing industri kecil gula merah sehubungan dengan berbagai masalah yang dihadapinya.

\section{GAMBARAN UMUM DAN KONDISI IKGMT DI KABUPATEN KEDIRI}

Industri kecil gula merah yang berbahan baku dari tebu (IKGMT) di Kabupaten Kediri yang pada tahun 1999 berjumlah 415 unit usaha, pada tahun 2002 yang masih eksis dan beroperasi tinggal sebanyak 160 unit usaha atau 38,5 persen. Penurunan jumlah yang begitu tajam disebabkan oleh berbagai alasan yang sudah kronis, misalnya manusia kualitas sumber daya (SDM), teknologi produksi yang digunakan masih begitu sederhana, keterbatasan modal, jangkauan pasar yang masih terbatas serta masalahmasalah lingkungan eksternal lainnya yang begitu komplek. Namun yang menjadi pemicu utama adalah jatuhnya harga gula merah pada tahun 2001 yang lalu. Data sekunder yang dapat memberikan gambaran tentang profil IKGMT di Indonesia tidak sebanyak yang dimiliki oleh industri gula pasir atau putih, bahkan dapat dikatakan sangat minim. Hal di atas barangkali karena industri gula pasir adalah milik pemerintah, sehingga memiliki data yang lengkap, misalnya data tentang produksi, impor, ekspor, konsumsi dan stok setiap tahun selalu tercatat dengan relatif baik. Di samping itu juga memiliki lembaga-lembaga, seperti Pusat Penelitian Perkebunan Gula Indonesia (P3GI), Sekretariat Dewan Gula dan Asosiasi Gula Indonesia dengan WARTA AGI-nya yang memberikan informasi tentang pergulaan nasional maupun dunia. 
Tabel 2.1 : Data Produksi, Impor, Ekspor,Konsumsi dan Stok Gula Pasir (Ton)

\begin{tabular}{|c|c|c|c|c|c|c|}
\hline \multirow[t]{2}{*}{ Tahun } & \multirow[t]{2}{*}{ Produksi } & \multirow[t]{2}{*}{ Impor } & \multirow[t]{2}{*}{ Ekspor } & \multicolumn{2}{|c|}{ Konsumsi } & \multirow[t]{2}{*}{ Stok } \\
\hline & & & & Nasional & Per Kapita & \\
\hline 1996 & 2.100 .477 & 975.830 & 0 & 3.073 .765 & 0.01520 & 488.946 \\
\hline 1997 & 2.196 .545 & 1.364 .563 & 0 & 3.373 .522 & 0,01675 & 676.532 \\
\hline 1998 & 1.496 .027 & 1.730 .473 & 0 & 2.739 .295 & 0,01346 & 1.163 .737 \\
\hline 1999 & 1.493 .067 & 995.536 & 0 & 3.000 .000 & 0,01446 & 652.340 \\
\hline 2000 & 1.685 .826 & 1.194 .165 & 0 & 3.000 .000 & 0,01410 & 532.331 \\
\hline
\end{tabular}

Sumber : Hafsah (2002)

Data dan informasi lain tentang gula pasir juga dapat ditemukan di Badan Pusat Statistik secara lebih lengkap dan juga dapat diperoleh dari SERI INFORMASI PASAR yang diterbitkan oleh Ditjen Perdagangan Dalam Negeri Deperindag. Bisnis gula pasir juga memiliki tata niaga sendiri, misalnya Keputusan Menteri Keuangan, Nomor : 324/KMK.01/2002 tanggal 3 Juli 2002 tentang perubahan Tarip Bea Masuk Atas Impor Gula dan Keputusan Menteri Perindustrian dan Perdagangan, Nomor :643/MPP/Kep/9/2002 tanggal 23 September, tentang Tata Niaga Gula Impor.

Tabel 2.2 : Data Produksi, Ekspor, Impor, Konsumsi dan Stok Gula Merah Secara Nasional (Ton)

\begin{tabular}{||c|c|c|c|c|c||}
\hline \hline Tahun & Produksi & Ekspor & Impor & Konsumsi & Stok \\
\hline 1998 & $2.988,174$ & - & - & - & - \\
1999 & 1.404 & - & - & - & - \\
2000 & 459,445 & - & - & - & - \\
\hline
\end{tabular}

Sumber : Suparyadi (2003)

Berbeda dengan data yang dimiliki oleh gula pasir, data yang dimiliki oleh gula merah tebu hanya dapat ditemukan di Deperindag dan BPS dan itupun patut dipertanyakan validitasnya, sebab Suparyadi (2003) dalam surveinya menemukan adanya produsen GMT yaitu $\mathrm{H}$. Ruba'i dari Desa Slumbung, Kecamatan Ngadiluwih Kabupaten Kediri yang sejak tahun 1997 mengekspor seluruh produknya (rata-rata 172 ton setahun) ke Jepang, tetapi data ini tidak tercatat pada lembaga-lembaga di atas (Tabel 2.2 dan tabel 2.3)

Bisnis GMT tidak diatur seperti halnya gula pasir, walaupun pengaturan itu belum tentu menjamin kondusifnya iklim bisnis GMT. Tetapi kenyataan membuktikan bahwa bisnis GMT sulit berkembang bahkan berpotensi menyusut seperti yang terjadi pada tahun 2001 yang lalu. 
Tabel 2.3 : Data Ekspor Gula Merah Tahun 1997 - 2001 Oleh H. Ruba'i

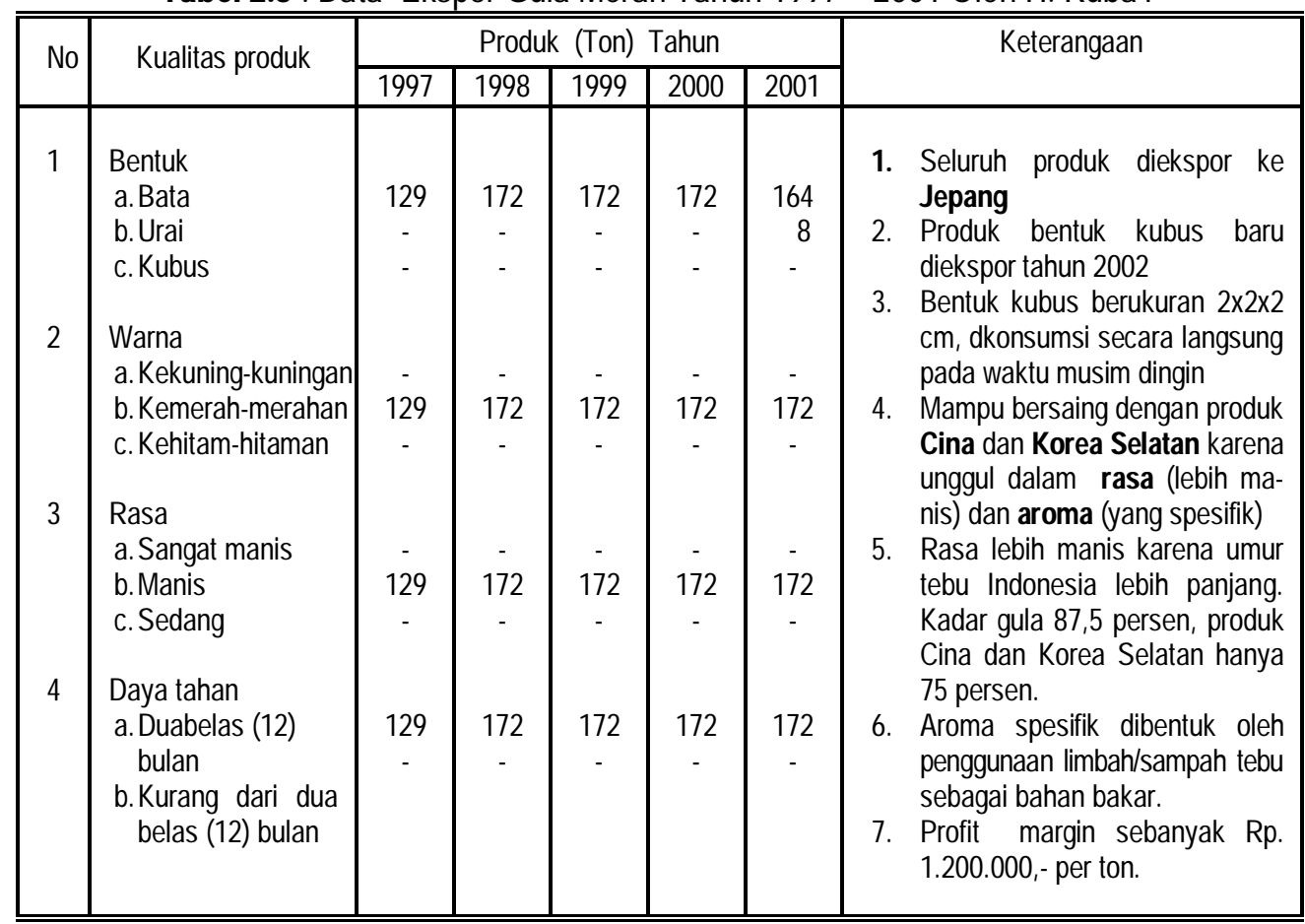

Sumber : Suparyadi (2003)

Kondisi IKGMT di atas didukung oleh hasil survei yang dilakukan oleh Suparyadi (2003) dengan melibatkan 160 rsponden yaitu pimpinan IKGMT, misalnya tentang peralatan produksi, kualitas dan peran SDM, produksi dan kualitas produk, volume penjualan, harga, laba dan beberapa permasalahan lain yang dihadapi oleh IKGMT. Temuan-temuan dari lapangan ini dapat memberikan gambaran lebih jelas kepada semua pihak, terutama yang peduli kepada industri kecil khususnya IKGMT, tentang profil IKGMT daripada sekedar data produksi yang tercatat di lembaga resmi pemerintah. Kondisi IKGMT sangat memprihatinkan, kepedulian berbagai pihak yang terkait sangat rendah, walaupun IKGMT berpotensi memberikan kontribusi yang signifikan terhadap perekonomian nasional baik dalam memasok GDP, penyerapan tenaga kerja, mengurangi kemiskinan maupun pemerataan distribusi pendapatan. Multiplier effect economy yang dapat ditimbulkannyapun dari waktu kewaktu dapat makin meluas karena apabila setelah dibina kemudian pendapatan para pemilik dan karyawan IKGMT maupun pihak-pihak yang terkait dapat meningkat maka otomatis bisnis sektor-sektor lain juga akan dapat mengalami peningkatan, dan demikian seterusnya. 
Tabel 2. 4 : Data Status Kepegawaian, Hubungan Keluarga, Pendidikan dan Latihan

\begin{tabular}{|c|c|c|c|c|c|}
\hline \multirow{2}{*}{ No } & \multirow{2}{*}{ Aspek } & \multirow{2}{*}{ Jenis / Tingkat } & \multicolumn{2}{|c|}{ Jumlah } & \multirow{2}{*}{ Keterangan } \\
\hline & & & Orang & $\%$ & \\
\hline 1. & $\begin{array}{l}\text { Status } \\
\text { Kepegawaian }\end{array}$ & $\begin{array}{l}\text { - Pegawai Tetap } \\
\text { - Pegawai Harian } \\
\text { - Pegawai harian } \\
\text { lepas }\end{array}$ & $\begin{array}{l}602 \\
260 \\
554\end{array}$ & $\begin{array}{l}41,51 \\
18,36 \\
39,12\end{array}$ & \multirow{4}{*}{$\begin{array}{l}\text { Jumlah pegawai/ } \\
\text { pekerja di } 160 \\
\text { industri gula } \\
\text { merah yang } \\
\text { disurvei sebanyak } \\
1.416 \text { orang }\end{array}$} \\
\hline 2 & $\begin{array}{l}\text { Status Hubungan } \\
\text { Keluarga }\end{array}$ & $\begin{array}{l}\text { - Keluarga Pemilik } \\
\text { Perusahaan } \\
\text { - Orang lain/bukan } \\
\text { keluarga }\end{array}$ & $\begin{array}{r}94 \\
1.322\end{array}$ & $\begin{array}{r}6,64 \\
93,36\end{array}$ & \\
\hline 3 & Pendidikan & $\begin{array}{l}\text { - SD atau sederajad } \\
\text { - SLTP atau sederajad } \\
\text { - SLTA atau sederajad } \\
\text { - Perguruan Tinggi }\end{array}$ & $\begin{array}{r}1.264 \\
102 \\
32 \\
18\end{array}$ & $\begin{array}{r}89,27 \\
7,20 \\
2,26 \\
1,27\end{array}$ & \\
\hline 4 & Pelatihan & $\begin{array}{l}\text { - Manajemen } \\
\text { - Teknik Produksi }\end{array}$ & $\begin{array}{l}19 \\
90\end{array}$ & $\begin{array}{l}1,34 \\
6,35 \\
\end{array}$ & \\
\hline
\end{tabular}

Sumber : Suparyadi (2003)

IKGMT pada umumnya didirikan di atas tanah yang cukup luas, milik sendiri, terletak di area pemukiman perdesaan. Peralatan produksi terdiri dari sebuah mesin penggiling tebu yang digerakkan oleh mesin disel, sebuah tungku pengapian yang di atasnya terdapat (kebanyakan) 7 (tujuh) buah wajan untuk memasak nira, sebuah bak atau wadah guna mendinginkan atau mengkristalkan gula yang sudah masak dan alat cetak (tempurung kelapa, cetakan batu merah, bambu atau paralon). Guna mendapatkan kualitias produksi yang baik dan standar, secara teknis peralatan ini kurang memadai, sebab diperlukan pengendalian yang ketat terhadap tingkat keasamaan nira, tingginya suhu pengapian, tingkat kemasakan gula dan kadar air gula. Produk yang memiliki kualitas baik adalah produk gula dengan rasa sangat manis dan berwarna kekuning-kuningan (Purnomo,1997) dan hasil ini dapat diperoleh apabila nilai pH nira berkisar antara 0,6 hingga 6,5, suhu nira dalam pengolahan tidak lebih dari 1100C, tingkat kemasakan atau kekentalan gula untuk siap dikeluarkan dari wajan harus mencapai derajad Brix di atas 85 persen dan untuk mencapai lama daya tahan tertentu harus memiliki kadar air gula tertentu. Peralatan ukur guna memastikan dipenuhinya standar teknis agar dihasilkan produk dengan kualitas baik tidak ada dan perannya digantikan oleh manusia yaitu para karyawan.

Jumlah karyawan pada setiap unit IKGMT sebanyak sekitar 8 orang, walaupun IKGMT merupakan industri kecil tetapi lebih dari 93 persen karyawannya terdiri dari bukan anggota keluarga. Hal ini terutama karena semua IKGMT sangat memerlukan tenaga kerja yang berpengala- 
man yang memiliki kemampuan menaksir nilai $\mathrm{pH}$ nira, tingginya suhu pengapian, derajat kekentalan gula yang sudah dinilai masak dan kadar air gula. Kualitas pendidikan karyawan rata-rata rendah yaitu sebanyak 89,27 persen hanya tamatan SD atau yang sederajat, sebanyak 7,20 persen tamatan SLTP, sebanyak 2,26 persen tamatan SLTA dan sebanyak 1,27 persen tamatan sekolah yang lebih tinggi daripada SLTA (Tabel 2.4)

Para pimpinan IKGMT yang sekaligus juga sebagai pemilik perusahaan, kualitas pendidikannya, sebagian besar juga rendah yaitu sebanyak 8,625 persen tidak bersekolah, sebanyak 55 persen tamatan SD, sebanyak 14,375 persen tamatan SLTP, sebanyak 26,25 persen tamatan SLTA dan sebanyak 3,75 persen tamatan PT. Namun demikian, mereka ini memiliki motivasi yang cukup baik dalam mendirikan IKGMT yaitu sebanyak 73,125 persen karena inisiatif sendiri (walaupun latar belakangnya berbeda) dan 26,875 persen diperoleh dari warisan orang tua (Tabel 2.5)

Tabel 2.5 : Data Tentang Aspek Motivasi Mendirikan Perusahan Gula Merah

\begin{tabular}{||l|l|r|r|l||}
\hline \multirow{2}{*}{ Aspek } & \multicolumn{1}{|c|}{ Macam } & \multicolumn{2}{c|}{ Jumlah } & \multirow{2}{*}{ Keterangan } \\
\cline { 3 - 4 } & & Orang & \multicolumn{1}{c||}{$\%$} & \\
\hline Motivasi mendirikan & - Inisiatif sendiri (usaha pokok) & 70 & 43,75 & Jumlah respon \\
perusahaan/industri & - Inisiatif sendiri (usaha sampingan) & 39 & 24,375 & den sebanyak \\
gula merah & - Mengikuti anjuran Pemerintah & 1 & 0,625 & 160 orang \\
& - Mengikuti teman/ Tetangga & 7 & 4,375 & \\
& - Mewarisi usaha orang tua/keluarga & 43 & 26,875 & \\
\hline
\end{tabular}

Sumber : Suparyadi (2003)

Dari aspek penggunaan bahan bakar, IKGMT sangat mendukung efisiensi biaya produksi karena bahan bakar yang digunakan adalah ampas tebu. Ampas tebu ini dijemur sehingga kering, disimpan dan digunakan sebagai bahan bakar, sehingga perusahaan tidak perlu mengeluarkan biaya pembuangan limbah dan membeli bahan bakar yang lain. Bahan bakar dari ampas tebu ini makin mempertajam aroma GMT yaitu spesifik tebu.

Kemampuan produksi setiap unit IKGMT rata-rata sekitar $700 \mathrm{~kg}$ per hari dengan lama kerja 10 jam atau rata-rata sekitar 100 ton per tahun dengan lama kerja sekitar 5-6 bulan. Produk yang dihasilkan kualitasnya tidak standar dan sebagian besar kurang baik yaitu rasa manis mencapai 92,37 persen dan warna kemerah-merahan mencapai sebanyak 81,57 persen, sedangkan yang berkualitas baik yaitu rasa sangat manis hanya sebanyak 31,47 persen dan warna kekuning-kuningan sebanyak 12,01 persen (tabel 2.6) 
Tabel 2.6 : Kualitas Produk Menurut Bentuk, Warna dan Rasa

\begin{tabular}{|c|c|c|c|c|c|}
\hline \multirow{3}{*}{ No } & \multirow{3}{*}{ Aspek } & \multirow{3}{*}{ Macam } & \multicolumn{3}{|c|}{ Jumlah } \\
\hline & & & \multirow[t]{2}{*}{ Produsen } & \multicolumn{2}{|c|}{ Produk (Ton) } \\
\hline & & & & Total & Rata - rata \\
\hline \multirow[t]{3}{*}{1} & \multirow[t]{3}{*}{ Bentuk Produk } & - Bata & 8 & 802,00 & 100,25 \\
\hline & & - Tempurung & 49 & $2.266,50$ & 46,25 \\
\hline & & - Urai & 147 & $13.963,00$ & 94,98 \\
\hline \multirow[t]{3}{*}{2} & \multirow[t]{3}{*}{ Warna Produk } & - Kehitam-hitaman & 63 & 953,37 & 15,13 \\
\hline & & - Kemerah-merahan & 132 & $12.129,60$ & 91,89 \\
\hline & & - Kekuning-kuningan & 43 & $1.786,50$ & 41,55 \\
\hline \multirow[t]{3}{*}{3} & \multirow[t]{3}{*}{ Rasa Produk } & - Sangat manis & 10 & 518,00 & 51,80 \\
\hline & & - Manis & 140 & $13.791,00$ & 98,51 \\
\hline & & - Sedang & 32 & 621,00 & 19,40 \\
\hline
\end{tabular}

Sumber : Suparyadi (2003)

Kualitas produk dari aspek daya tahan sebagian besar kurang baik yaitu sebanyak 48,125 persen berdaya tahan antara 2,5 samapai 4 bulan, sedangkan yang memiliki daya tahan selama 12 bulan hanya sebanyak 37,5 persen.

Konsumen yang terdiri dari para pengepul/tengkulak dan pedagang besar menyatakan bahwa berapapun jumlah produksi GMT, semua akan mereka beli. Namun ironisnya, hal ini tidak menjadikan harga GMT menjadi tinggi, walaupun 55 persen produsen menyatakan bahwa harga ditentukan berdasarkan tawar-menawar, sebanyak 42,5 persen menyatakan ditentukan oleh produsen. Kondisi ini diperburuk dengan kenyataan bahwa pasar mereka hampir seluruhnya di wilayah lokal Kabupaten Kediri, dengan saluran distribusi langsung yaitu konsumen rumah tangga lokal dan terbanyak dikonsumsi oleh tengkulak/pengepul dan pedagang besar yaitu 96,03 persen. (Tabel 2.7)

Walaupun seluruh produksi habis terjual, tetapi dengan kondisi pasar seperti di atas maka laba yang diperoleh produsen tidak memadai yaitu laba yang diperoleh dari konsumen rumah tangga lokal sebesar Rp. 451.200,-per ton dan dari konsumen bisnis lokal mencapai Rp. 243.600,per ton. Laba total yang diperoleh rendah atau sedikit karena volume penjualan ke konsumen rumah tangga lokal hanya 3,47 persen dan yang terbanyak justru kepada konsumen bisnis yaitu sebanyak 96,03 persen (Tabel 2.8) 
Tabel 2.7: Volume Penjualan Menurut Segmen dan Pasar Sasaran Tahun 1997 - 2001

\begin{tabular}{|c|c|c|c|c|c|}
\hline \multirow[b]{2}{*}{ Tahun } & \multirow[b]{2}{*}{ Volume Penjualan } & \multicolumn{3}{|c|}{ Pasar } & \multirow[b]{2}{*}{$\begin{array}{c}\text { Jumlah } \\
\text { Total }\end{array}$} \\
\hline & & $\begin{array}{c}\text { RumahTangga } \\
\text { Lokal }\end{array}$ & $\begin{array}{l}\text { Bisnis } \\
\text { Lokal }\end{array}$ & $\begin{array}{c}\text { Bisnis } \\
\text { Regional }\end{array}$ & \\
\hline \multirow[t]{3}{*}{1997} & Total (Ton) & 519,80 & $14.070,20$ & 77,00 & 14.667 \\
\hline & Persentase & 3,54 & 95,93 & 0,52 & 100 \\
\hline & Rata - rata (Ton) & 9,28 & 87,94 & 38,50 & \\
\hline \multirow[t]{3}{*}{1998} & Total (Ton) & 591,80 & $14.250,70$ & 77,50 & 14.920 \\
\hline & Persentase & 3,97 & 95,51 & 0,52 & 100 \\
\hline & Rata - rata (Ton) & 10,57 & 89,07 & 38,75 & \\
\hline \multirow[t]{3}{*}{1999} & Total (Ton) & 494,33 & $14.756,17$ & 77,50 & 15.328 \\
\hline & Persentase & 3,23 & 96,26 & 0,51 & 100 \\
\hline & Rata - rata (Ton) & 8,83 & 92,23 & 38,75 & \\
\hline \multirow[t]{3}{*}{2000} & Total (Ton) & 497,55 & $15.338,95$ & 65,50 & 15.902 \\
\hline & Persentase & 3,13 & 96,46 & 0,41 & 100 \\
\hline & Rata - rata (Ton) & 8,89 & 95,87 & 32,75 & \\
\hline \multirow[t]{3}{*}{2001} & Total (Ton) & 573,35 & $15.531,15$ & 79,50 & 16.184 \\
\hline & Persentase & 3,54 & 95,97 & 0,49 & 100 \\
\hline & Rata - rata (Ton) & 10,24 & 97,07 & 39,75 & \\
\hline
\end{tabular}

Sumber : Suparyadi (2003)

Tabel 2.8: Perolehan Laba Menurut Segmen dan Pasar Sasaran Tahun 1997 - 2001

\begin{tabular}{|c|c|c|c|c|c|}
\hline \multirow[b]{2}{*}{ Tahun } & \multirow[b]{2}{*}{ Laba (Juta Rupiah) } & \multicolumn{3}{|c|}{ Pasar } & \multirow{2}{*}{$\begin{array}{c}\text { Jumlah } \\
\text { Total }\end{array}$} \\
\hline & & $\begin{array}{c}\text { Rumah Tangga } \\
\text { Lokal }\end{array}$ & $\begin{array}{l}\text { Bisnis } \\
\text { Lokal }\end{array}$ & $\begin{array}{c}\text { Bisnis } \\
\text { Regionall }\end{array}$ & \\
\hline \multirow[t]{3}{*}{1997} & Total & 209,296 & $3.325,389$ & 20 & $3.554,6$ \\
\hline & Rata-rata per ton & 0,403 & 0,236 & 0,260 & \\
\hline & Rata-rata per produsen & 3,737 & 20,784 & 10 & \\
\hline \multirow[t]{3}{*}{1998} & Total & 270,023 & $3.659,661$ & 20,50 & $3.950,1$ \\
\hline & Rata-rata per ton & 0,456 & 0,255 & 0,625 & \\
\hline & Rata-rata per produsen & 4,822 & 22,873 & 10,25 & \\
\hline \multirow[t]{3}{*}{1999} & Total & 227,532 & $3.610,551$ & 25,50 & $3.863,5$ \\
\hline & Rata-rata per ton & 0,460 & 0,244 & 0,329 & \\
\hline & Rata-rata per produsen & 4,063 & 22,566 & 12,75 & \\
\hline \multirow[t]{3}{*}{2000} & Total & 226,936 & $3.610,201$ & 30,50 & $3.867,6$ \\
\hline & Rata-rata per ton & 0,456 & 0,238 & 0,466 & \\
\hline & Rata-rata per produsen & 4,052 & 22,564 & 15,25 & \\
\hline \multirow[t]{3}{*}{2001} & Total & 275,648 & $3.803,196$ & 10,70 & $4.089,5$ \\
\hline & Rata-rata per ton & 0,481 & 0,245 & 0,135 & \\
\hline & Rata-rata per produsen & 4,922 & 23,770 & 5,35 & \\
\hline
\end{tabular}

Sumber : Suparyadi (2003) 
Laba penjualan yang diperoleh dari pasar lokal, sangat jauh lebih rendah daripada yang diperoleh $\mathrm{H}$. Ruba'IKGMT dari pasar Jepang yaitu sebesar Rp. 1.200.000,- per ton. Hal ini menunjukkan betapa timpangnya pendapatan antara pasar lokal dan pasar ekspor, sekaligus juga menunjukkan adanya potensi dan peluang yang dapat digarap oleh para produsen GMT di pasar ekspor.

\section{BEBERAPA FAKTOR YANG MEMPENGARUHI KINERJA PEMASARAN IKGMT}

Pada bagian depan telah dijelaskan bahwa banyak sekali faktor yang mempengaruhi kinerja pemasaran perusahaan, baik aspek volume penjualan, laba maupun pangsa pasar. Pada bagian ini yang akan dibahas hanya sebagian saja, dibatasi pada masalah yang terkait dengan pokok bahasan tulisan ini yaitu tentang keunggulan bersaing. Faktor-faktor yang hendak dibahas yaitu teknologi produksi, SDM, keuangan, kekuatan sosial dan budaya serta kekuatan politik dan hukum dalam hubungannya dengan produk, harga, volume penjualan dan laba.

Dari tabel 2.6 dapat dilihat bahwa dari aspek warna dan rasa menunjukkan tidak standarnya kualitas produk dan sebagian besar berkualitas kurang baik. Kualitas produk yang tidak standar dan kurang baik juga ditunjukkan oleh daya tahannya yang sangat variatif mulai dari 2,5 bulan sampai 12 bulan dan sebagain besar berdaya tahan antara 2,5 4 bulan. Pengaruh teknologi produksi terhadap kualitas produk signifikan, karena walaupun sebanyak 93,75 persen responden menyatakan bahwa bahan baku utama (tebu) memiliki kualitas yang cukup baik atau baik, ternyata kualitas produk mereka didominasi oleh produk yang berwarna kemerah-merahan dan rasa manis bahkan terdapat produk yang berwarna kehitam-hitaman dengan rasa pahit sebanyak 6,41 persen. Hal ini dapat terjadi dengan penyebab utama adalah tiadanya beberapa alat pengukur yang diperlukan dan human error. Ketiadaan beberapa alat pengukur ini bukan merupakan kelalaian manajer perusahaan, tetapi desain peralatan produksinya memang demikian. Purnomo (1997) mengatakan bahwa apabila nilai $\mathrm{pH}$ nira lebih tinggi dari 6,5 atau suhu pengapian melebihi $1100 \mathrm{C}$, maka hasil yang diperoleh adalah gula yang berwarna kemerah-merahan cenderung kehitam-hitaman dan rasanya agak pahit. Angka-angka ini adalah ukuran yang pasti dan untuk memastikannya harus diukur dengan alat yang mampu mengidentifikasi secara tepat. Jadi bukan dengan pengamatan mata telanjang kemudian dibuat perkiraan. Walaupun para karyawannya sangat berpengalaman, potensi terjadinya human error sangat terbuka karena misalnya kondisi kesehatan dan kebugaran karyawan (harus bekerja 10 jam per hari) kurang baik serta kemungkinan adanya masalah-masalah pribadi dan lain-lain. Tingkat daya tahan produk 
dapat dicapai melalui 2 (dua) tahap yaitu ketika nira yang dimasak kekentalannya sudah mencapai derajad Brix di atas 85 persen baru boleh dikeluarkan dari wajan dan yang kedua yaitu nira panas ini dimasukkan ke bak atau wadah untuk didinginkan atau dikristalkan. Untuk mengetahui secara pasti derajad Brix dan kadar air kristal gula juga tidak mungkin dilakukan dengan pengamatan, harus melalui alat ukur yang standar.

Kondisi kualitas GMT di atas diperkuat oleh hasil uji statistik bahwa pengaruh bahan baku yang baik terhadap kualitas produk tidak signifikan. Hal ini berarti bahwa kualitas bahan baku yang baik tidak secara otomastis menghasilkan produk dengan kualitas yang baik pula, tetapi masih tergantung pada pengaruh faktor lain dan dalam kasus ini pengaruh teknologi terhadap kualitas produk lebih signifikan daripada pengaruh kualitas bahan baku.

Kualitas produk secara tidak langsung juga dipengaruhi oleh pesaing dan tingkat persaingan maupun oleh preferensi pasar. Pesaing dan persaingan maupun preferensi pasar merupakan insentif bagi produsen untuk menentukan kualitas produk yang akan dihasilkan oleh perusahannya. Apabila dilihat dari aspek industri, baik dalam fungsinya sebagai sumber energi maupun sumber pemanis, pesaing GMT sangat banyak, misalnya gula pasir, gula merah kelapa, gula merah aren, sakarin dan sejenisnya, lemak, minyak, jagung, umbi-umbian dan lain-lain. Tetapi apabila dilihat dari aspek segmen pasar, pesaing GMT tentu berkurang karena misalnya bahan pemanis atau lemak tidak akan memasuki segmen industri kecap. Walaupun pesaing GMT cukup banyak, namun kondisi persaingan sangat kondusif dan cenderung stagnan, tidak terjadi gejolak perebutan posisi bersaing dalam rangka meningkatkan pangsa pasar yang berujung pada meningkatnya kemampulabaan perusahaan. GMT "tidak merasa" disaingi oleh gula pasir, gula merah kelapa maupun gula merah aren karena harga GMT lebih murah daripada ketiga gula yang lain. GMT juga "tidak merasa" disaingi oleh bahan-bahan pemanis, karena segmen pasarnya berbeda. Kalaupun pada suatu ketika, gula jenis yang lain menggantikan posisi GMT, sifatnya sebagai produk substitusi tidak penuh karena GMT memiliki ciri-ciri khusus, misalnya rasa manis yang spesifik, aroma yang spesifik dan harga yang lebih murah karena dapat diproduksi secara massal. Kualitas GMT juga dipengaruhi oleh preferensi pasar, walaupun pengaruh ini tidak secara langsung. Pasar konsumen (rumah tangga) maupun pasar industri (termasuk bisnis) tidak menentukan syarat-syarat kualitas tertentu yang harus dipenuhi oleh produk GMT. Hal ini dapat dibuktikan dengan habis terjualnya seluruh hasil produksi, termasuk produk yang kualitasnya paling jelek yaitu produk yang tidak dapat mengkristalberwarna hitam- rasanya pahit. Produk dengan kualitas terjelek ini walaupun memiliki segmen pasar tersendiri yaitu industri petis, tetapi 
harganya murah. Namun demikian, ternyata hal ini juga tidak mendorong produsen GMT untuk meningkatkan kualitas produknya.

Produk IKGMT dengan kualitas yang kurang baik dan tidak standar itu juga dipengaruhi oleh kualitas SDM yang sebagian besar rendah baik pada tingkat pimpinan maupun karyawan. Dengan pendidikan hanya sebatas SD, daya kreativitas dan inovasinya sangat terbatas, wawasannya begitu pendek dan bekerja lebih mengandalkan pada kebiasaan atau pengalaman. Pendeknya wawasan serta rendahnya daya kreativitas dan inovasi, membuat mereka tidak berpikir tentang perubahan, perbaikan, kemajuan, peningkatan atas kualitas produk bahkan kualitas hidupnya sendiri. Untuk melakukan perubahan yang sangat sederhana saja yaitu merubah bentuk produk tempurung menjadi bentuk bata atau yang lain, mereka tidak mau dengan alasan sudah terbiasa membuat produk bentuk tempurung. Kualitas SDM ini merupakan salah satu masalah penting yang perlu diperhatikan dalam rangka pengembangan IKGMT agar keberadaannya dapat menjadi sumber kreativitas dan inovasi perusahaan.

Kemampuan produksi setiap unit IKGMT adalah $700 \mathrm{Kg}$ per hari atau sekitar 100 ton per tahun, nampaknya sudah optimal, karena walaupun setiap tahun mengalami kenaikan jumlah produksi, tetapi kenaikannya tidak signifikan yaitu rata-rata hanya 2,17 persen per tahun (Tabel 3.1).

Tabel 3.1: Peningkatan / Penurunan Volume Penjualan Menurut Segmen dan Pasar Sasaran Tahun 1997-2001

\begin{tabular}{|c|c|c|c|c|c|}
\hline \multirow[b]{2}{*}{ Tahun } & \multirow{2}{*}{$\begin{array}{l}\text { Peningkatan/Penu } \\
\text { Runan Volume } \\
\text { Penjualan (Ton) }\end{array}$} & \multicolumn{3}{|c|}{ Pasar } & \multirow[b]{2}{*}{ Jumlah } \\
\hline & & $\begin{array}{c}\text { Rumah Tangga } \\
\text { Lokal }\end{array}$ & $\begin{array}{l}\text { Bisnis } \\
\text { Lokal }\end{array}$ & $\begin{array}{c}\text { Bisnis } \\
\text { Regional }\end{array}$ & \\
\hline \multirow[t]{3}{*}{1997} & Naik & 5,07 & 141,55 & 0,05 & 146,67 \\
\hline & Turun & 0 & 0 & 0 & 0 \\
\hline & Total & 5,07 & 141,55 & 0,05 & 146,67 \\
\hline \multirow[t]{3}{*}{1998} & Naik & 94,50 & 448,00 & 0,50 & 543,00 \\
\hline & Turun & 3,00 & 23,00 & 0 & 26,00 \\
\hline & Total & 91,50 & 425,00 & 0,50 & 517,00 \\
\hline \multirow[t]{3}{*}{1999} & Naik & 4,30 & 546,00 & 0 & 550,30 \\
\hline & Turun & 99,00 & 311,50 & 0 & 410,50 \\
\hline & Total & $(-) 94,70$ & 234,50 & 0 & 139,80 \\
\hline \multirow[t]{3}{*}{2000} & Naik & 15,20 & 567,90 & 0 & 583,10 \\
\hline & Turun & 12,00 & 63,60 & 0 & 75,60 \\
\hline & Total & 3,20 & 504,30 & 0 & 507,50 \\
\hline \multirow[t]{3}{*}{2001} & Naik & 77,00 & 291,00 & 2 & 370,00 \\
\hline & Turun & 1,20 & 9,00 & 0 & 10,20 \\
\hline & Total & 75,80 & 282,00 & 2 & 359,80 \\
\hline
\end{tabular}

Sumber : Suparyadi (2003) 
Semua hasil produksi terjual habis, bahkan pasar (pengepul/tengkulak dan pedagang besar) masih sanggup menyerap produk berapapun banyaknya. Namun justru produsen tidak mampu memenuhi permintaan pasar karena keterbatasan kemampuannya, terutama di bidang teknologi produksi dan keuangan. Peralatan produksi yang digunakan semi tradisional dan kapasitas produksinya terbatas, di sisi lain, untuk menghasilkan produk sebanyak $700 \mathrm{Kg}$ per hari, para karyawan sudah bekerja selama 10 (sepuluh) jam. Kondisi kerja ini menunjukkan bahwa kemampuan karyawan telah dicurahkan secara optimal. Apabila jam kerja untuk karyawan ditambah, justru perusahaan akan menanggung kerugian, karena kamampuan produksi makin menurun tetapi biaya operasional tetap. Disamping itu juga berpotensi besar terjadi kecelakaan kerja dan kualitas produk yang makin menurun karena terjadinya kelelahan fisik dan mental karyawan.

Teknologi produksi IKGMT saat ini sudah tidak mungkin untuk meningkatkan produktivitas dan kondisi ini diperburuk dengan terbatasnya kemampuan keuangan IKGMT. Sebanyak 160 unit IKGMT memiliki modal operasional sebanyak Rp. 5.592 milyar atau rata-rata sebanyak Rp. 34,95 juta per unit IKGMT. (tabel 3.2). Apabila biaya memproduksi GMT per ton rata-rata mencapai Rp. 1.384 juta maka modal yang dimiliki hanya mampu untuk memproduksi sebanyak 25,25 ton atau 36 hari bekerja. Begitu terbatasnya kemampuan keuangan IKGMT sehingga tidak dapat memenuhi kebutuhan operasional selama satu musim giling (5-6 bulan per tahun), oleh karena itu IKGMT tidak mungkin melakukan investasi teknologi guna meningkatkan produktivitas perusahaan.

Tabel 3.2: Data Kepemilikan Modal Usaha

\begin{tabular}{||c|l|c|c||}
\hline \multirow{2}{*}{ Aspek } & \multirow{2}{*}{ Macam } & \multicolumn{2}{|c||}{ Jumlah } \\
\cline { 3 - 4 } & & Rp (miliar) & $\%$ \\
\hline Modal Usaha & - Milik sendiri & 4,443 & 79,46 \\
& - Kredit/pinjaman & 1,149 & 20,54 \\
\hline \multicolumn{2}{|c|}{ Total } & 5,592 & 100 \\
\hline
\end{tabular}

Sumber : Suparyadi (2003)

Faktor-faktor pasar, perantara dan keuangan dapat mempengaruhi harga produk GMT. Pasar yang bersifat lokal, tidak mampu memberikan profit margin yang memadai, apalagi apabila dibandingkan dengan profit margin yang diperoleh $\mathrm{H}$. Ruba'i di pasar Jepang. Perbandingannya sangat timpang yaitu Rp. 451.200,- (paling tinggi) dengan Rp. 1.200.000,- atau 1 (satu) berbanding 2,66 padahal sebagian besar hanya mendapatkan profit 
margin Rp. 243.600,- atau perbandingannya menjadi 1 (satu) berbanding 4,93. Kondisi harga GMT di pasar lokal ini bertentangan dengan adanya permintaan pasar yang masih banyak. Secara teori, apabila permintaan lebih besar daripada penawaran, maka akan terjadi kenaikan harga. Berdasarkan teori ini, kadang-kadang industri sengaja mengurangi produksi guna menaikkan harga produk. Kondisi harga GMT di pasar lokal ini menyimpang dari teori karena adanya dominasi peran pedagang perantara. Para produsen GMT dalam menjual produknya bertindak sendiri-sendiri, mereka tidak memiliki perkumpulan, sementara kemampuan produksi setiap unit IKGMT hanya mencapai $700 \mathrm{Kg}$ per hari. Konsumen industri, misalnya pabrik kecap ABC yang setiap hari memerlukan GMT sebanyak 90 ton, tidak efisien apabila membeli GMT langsung dari produsen. Oleh karena itu, konsumen industri seperti ini membeli GMT melalui pedagang perantara. Di sinilah letaknya dominasi peran pedagang perantara dalam bisnis GMT. Mereka mula-mula berani memberikan uang muka dengan tujuan untuk memastikan mendapat pasokan GMT dari produsen, kemudian secara sadar atau tidak, telah berkembang menjadi lembaga keuangan disamping tetap sebagai pedagang perantara. Berkembangnya peran sebagai lembaga keuangan ini memang sangat mungkin, sebab para produsen mengalami kesulitan modal. Perkembangan selanjutnya adalah wajar apabila kemudian yang menentukan harga GMT adalah para perantara. Hal ini didukung oleh hasil survei, walalupun sebanyak 55 persen produsen menyatakan bahwa harga ditentukan berdasarkan tawarmenawar, tetapi sebanyak 42,5 persen menyatakan ditentukan oleh konsumen dibanding hanya sebanyak 2,5 persen menyatakan ditentukan oleh produsen.

Lemahnya posisi tawar produsen GMT dalam mendapatkan harga jual yang tinggi juga disebabkan oleh keterbatasan kemampuan keuangan perusahaan. Kemampuan modal kerja yang hanya mampu untuk beroperasi selama 36 hari, tidak memungkinkan produsen menyimpan produknya lebih lama guna menunggu harga GMT naik, untuk kemudian menjualnya. Dalam praktek, setiap sore hari ketika kegiatan memproduksi hari itu sudah berakhir, produk GMT langsung diambil oleh para pedagang perantara (pengepul/tengkulak dan pedagang besar). Praktek seperti ini oleh para produsen disikapi sebagai "berkah" karena mereka tidak perlu berkeliling menawarkan produknya, apabila dijual kepada selain kepada pedagang perantara belum tentu habis terjual, padahal mereka memerlukan cash flow untuk biaya operasional esok paginya dan mereka merasa mendapat sejumlah keuntungan lainnya.

Perkembangan jaman telah merubah gaya hidup masyarakat terutama di perkotaan. Kini sudah biasa ditemui suami-istri bekerja, anakanak di samping sekolah juga mengikuti berbagai kursus atau les pribadi, 
keluarga atau para remaja berkreasi setiap malam hari libur. Kondisi seperti ini "memaksa" mereka untuk makan di luar rumah, di restoran atau warungwarung bahkan pedagang kaki lima (PKL), guna menyantap makanan siap saji. Makanan ini banyak diantaranya yang menggunakan sebagain bahan bakunya adalah GMT. Karena tren gaya hidup masyarakat seperti ini makin berkembang, maka berarti bahwa kebutuhan GMT semakin banyak atau dengan kata lain makin terbuka peluang untuk meningkatkan volume penjualan. Dengan demikian, walaupun mungkin profit margin belum meningkat, tetapi setidak-tidaknya, produsen dapat menikmati meningkatnya laba total. Pada satu sisi, peluang meningkattnya volume penjualan sangat besar, tetapi disisi lain, meningkatnya permintaan belum tentu diikuti dengan meningkatnya kualitas produk. Hal ini disebabkan GMT tidak dikonsumsi secara langsung (di pasar lokal), tetapi GMT dikonsumsi sebagai salah satu bahan baku produk olahan, misalnya kecap, kembang gula, kue-kue tradisional dan lain-lain. Karena yang dikonsumsi adalah produk olahan, maka apabila konsumen memperoleh kepuasan, yang mendapat pujian bukan GMTnya tetapi produk olahannya itu dan demikian pula apabila konsumen kecewa, maka kekecewaan itu ditujukan kepada produk olahannya.

Sejalan dengan GBHN 1999-2004 yang mengamanatkan pembangunan ekonomi kerakyatan, pemerintah pada tahun 2003 konon mengucurkan dana untuk UKM dalam jumlah puluhan triliun. Kebijakan makro pemerintah ini jelas sangat baik, tidak hanya karena sesuai dengan amanat GBHN, tetapi dana itu benar-benar dibutuhkan oleh UKM, termasuk IKGMT. Tidak tahu apa yang menjadi penyebab, tetapi yang pasti banyak UKM termasuk IKGMT tidak menikmati kucuran dana tersebut. Kemungkinan yang menjadi penyebabnya dapat saja, misalnya perencanaan yang kurang terarah -kurang terintegrasi- kurang terinci atau mungkin basa-basi politik untuk menyenangkan wong cilik? Namun yang pasti adalah bahwa dunia perbankan tidak mau royal mengucurkan dana kepada UKM, mereka tetap menuntut dipenuhinya persyaratan teknis guna memperoleh kredit oleh UKM. Perbankan mematok syarat ini karena mereka ingin menciptakan dan mempertahankan kinerja unggul, oleh karena itu mereka tidak ingin menanggung resiko terjadinya kredit macet. Kegamangan memberikan kredit kepada UKM ini secara jujur diakui oleh Direktur Utama bank Jatim bahwa pada tahun 2003 pihaknya menyalurkan kredit sebesar Rp. 3,3 triliun, namun yang diperuntukkan UKM hanya sebesar 10 persen (Jawa Pos, Senin 29 Desember 2003).

Ini adalah lingkaran setan. Perbankan menuntut adanya agunan bagi para peminjam kredit guna mengantisipasi kemungkinan terjadinya kredit macet, tetapi UKM tidak mungkin menyediakan agunan karena memang tidak mempunyainya - kemampuan mereka serba kecil. Masalah lingkaran setan ini sudah "sejak dulu kala" terjadi, tetapi nampaknya belum 
ada pihak-pihak yang secara serius ingin memecahkan masalah ini. Pemerintah yang memiliki kewenangan membuat kebijakan publik baik yang bersifat mengatur, mengerahkan maupun mengkoordinasikan segenap kekuatan dan potensi nasional, belum menggunakan kewenangannya secara baik dan buktinya adalah masih kokohnya lingkaran setan itu.

\section{KEUNGGULAN BERSAING : KEUNGGULAN BIAYA DAN DIFERENSIASI}

Pada bagian ini yang hendak dibahas adalah bagaimana agar IKGMT mampu bersaing dan unggul ketika harus menghadapi pesaingpesaing industri yang berasal dari negara lain, baik ketika IKGMT melakukan penetrasi terhadap pasar ekspor maupun apabila produk GMT negara lain yang merambah pasar dalam negeri. Pemikiran ini didasarkan pada suatu kenyataan bahwa sampai dengan saat ini dan entah sampai kapan, kondisi persaingan bisnis GMT di tingkat lokal sampai nasional nampak pasif. Kedua, H. Ruba'i dapat menembus pasar ekspor karena produknya memiliki keunggulan bersaing di aspek rasa yang lebih manis daripada pesaing dan aroma GMT yang spesifik, tetapi kalah bersaing di beberapa aspek, misalnya daya tahan dan konsistensi kualitas produk. Ketiga, guna mengantisipasi masuknya produk negara lain ke pasar dalam negeri atau hadirnya investor baru di IKGMT yang mengimplementasikan sejumlah sumber keunggulan bersaing.

Menurut Porter (1994), keunggulan bersaing tidak dapat dipahami dengan cara memandang sebuah perusahaan sebagai suatu keseluruhan, tetapi harus dari asal keunggulan bersaing itu yaitu berbagai aktivitas berlainan yang dilakukan oleh perusahaan dalam mendesain, memproduksi, memasarkan, menyerahkan dan mendukung produknya. Guna mengetahui sumber keunggulan bersaing, perlu dilakukan analisis terhadap semua aktivitas yang dilakukan oleh perusahaan, dengan menggunakan alat yang diperkenalkan oleh Porter (1994) sebagai rantai nilai . Nilai yang dimaksudkan di sini adalah suatu jumlah tertentu yang dibayarkan oleh pembeli atas apa yang diberikan oleh perusahaan kepada mereka. Analisis rantai nilai lebih tepat untuk meneliti keunggulan bersaing daripada nilai tambah (harga jual dikurangi biaya pembelian bahan baku), karena analisis ini dapat mengetahui nilai-nilai yang dimiliki semua aktivitas, sehingga dapat diketahui asal atau sumber dari keunggulan bersaing itu.

Makalah ini diawali dengan mengemukakan pandangan teoritik beberapa praktisi pemasaran erhadap kasus-kasus customer satisfaction yang mereka hadapi, karena dalam membahas keunggulan bersaing tidak dapat dipisahkan dengan masalah kepuasan pelanggan. Masalah kepuasan pelanggan berkisar pada seberapa besar nilai suatu produk dapat memenuhi harapan pelanggan, tetapi juga bagaimana supaya unik sehingga 
lebih unggul daripada produk pesaing dan dengan demikian pelanggan yang merasa puas itu menjadi loyal. Loyalitas ini terbentuk karena nilai produk yang ditawarkan oleh perusahaan melebihi harapan pelanggan dan nilai lebih ini diciptakan oleh keunikan produk. Menurut Agung (2001), loyalitas inilah yang bertanggung jawab terhadap profitabilitas, karena pelanggan yang loyal akan banyak membeli dan cenderung tidak peka terhadap harga. Di samping membahas hal yang terkait dengan produk, keunggulan bersaing dengan rantai nilainya, juga membahas aktivitas-aktivitas perusahaan yang lain yang terdiri dari 9 (sembilan) kategori generik aktivitas primer dan aktivitas pendukung. Aktivitas primer terdiri dari 5 (lima) kategori yaitu logistik ke dalam, operasi, logistik ke luar, pemasaran dan penjualan, serta pelayanan; sedangkan aktivitas pendukung terdiri dari 4 (empat) kategori yaitu pembelian, pengembangan teknologi, manajemen sumber daya manusia dan infrastruktur perusahaan (Porter, 1994).

Nilai vital setiap kategori tidak selalu sama antara satu industri dengan industri yang lain, misalnya kategori pelayanan (pemasangan, reparasi, pelatihan, pasokan suku cadang dan penyesuaian produk) akan bernilai vital untuk industri televisi, tetapi tidak ada nilainya untuk industri GMT. Untuk aktivitas pemasaran di pasar lokal regional maupun internasional, industri televisi memerlukan iklan, tetapi untuk IKGMT lebih memerlukan tenaga penjualan. Dengan adanya perbedaan-perbedaan kepentingan setiap kategori bagi industri-industri yang berbeda, maka pembahasan keunggulan bersaing IKGMT akan dibatasi pada kategori-kategori yang dinilai vital bagi IKGMT, selanjutnya dikaitkan dengan keunggulan biaya maupun diferensiasi.

Keunggulan biaya merupakan salah satu dari keunggulan bersaing yang mungkin dimiliki oleh perusahaan dan banyak manajer menetapkan "keunggulan biaya " atau "pengurangan biaya" sebagai tujuan. Namun banyak telaah biaya yang cenderung hanya memperhatikan biaya manufaktur dan mengabaikan dampak aktivitas lainnya seperti pemasaran, pelayanan, infrastruktur dan lain-lain terhadap posisi biaya relatif serta keterkaitan antara sejumlah aktivitas tersebut yang dapat mempengaruhi biaya. Posisi biaya perusahaan berasal dari perilaku biaya aktivitas nilainya dan perilaku biaya ini tergantung pada sejumlah faktor struktural (penentu biaya) yang dapat mempengaruhi biaya. Beberapa penentu biaya utama yang menentukan perilaku biaya aktivitas nilai yaitu ekonomi skala, pembelajaran, pola pendayagunaan kapasitas, keterkaitan, antarhubungan, pemaduan, penetapan waktu, kebijakan deskrit, lokasi dan faktor-faktor kelembagaan. Namun beberapa penentu biaya yang cenderung lebih sanggup bertahan daripada yang lain adalah ekonomi skala, antar hubungan, keterkaitan, pembelajaran dan pilihan kebijakan (Porter, 1994). Walaupun beberapa penentu biaya ini cenderung lebih sanggup bertahan, 
namun keunggulan biaya pada dasarnya dapat dipertahankan apabila terdapat hambatan masuk, artinya bahwa pesaing tidak mudah meniru.

Dalam kasus IKGMT, perusahan tidak perlu menyediakan fasilitas gudang yang luas, walaupun bahan baku yang diperlukan dalam satu musim giling (5-6 bulan dalam setahun) cukup banyak, sebab kapasitas produksi yang rendah $(700 \mathrm{Kg}$ per hari atau 7 Ton tebu) dan dalam 36 jam setelah ditebang, tebu harus sudah digiling agar rendeman tidak menurun, apabila terjadi penurunan rendeman maka perolehan GMT juga akan menurun (Supriyadi, 1992). Gudang yang tidak luas dan persediaan bahan baku yang tidak melebihi kapasitas produksi, dapat terlaksana dengan baik karena adanya kerjasama antara produsen dengan pemasok dalam bentuk penentuan jadwal tebang dan pengangkutan tebu dari sawah ke lokasi IKGMT. Hal ini merupakan bentuk implementasi aktivitas nilai logistik ke dalam dengan faktor penentu biaya ekonomi skala dan keterkaitan. Namun demikian, keunggulan biaya yang diciptakan ini memiliki kerawanan terhadap serangan pesaing, karena kerjasama antara produsen dengan pemasok tidak dituangkan dalam bentuk kontrak kerjasama atau membentuk corporate farming (digagas oleh pemerintah pada tahun 2000) yaitu suatu lembaga bersama yang memiliki beberapa unit usaha yang saling menunjang.

Dalam aktivitas nilai operasi khususnya tentang permesinan (pengolahan dan pencetakan) dan pengembangan teknologi, pilihan atas peralatan dan teknologi produksi yang ada di IKGMT saat ini sulit untuk menciptakan keunggulan biaya, karena terdapat beberapa kelemahan, misalnya tidak adanya 4 (empat) macam alat ukur, tercecernya nira ketika dipindahkan dari satu wajan ke wajan yang lain, pemindahan nira dan pencetakan dilakukan secara manual sehingga perlu waktu relatif lama. Proses produksi yang didominasi oleh tenaga kerja manusia ini, menghasilkan produk yang kualitsnya rendah dan tidak standar serta produktivitasnya rendah dan sudah tidak dapat ditingkatkan lagi. Setiap karyawan dapat diklasifikasikan memiliki keahlian tertentu, oleh karena itu hal ini merupakan titik rawan dalam menciptakan keunggulan biaya. Produk dengan kualitas yang rendah dan tidak standar sulit mendukung keunggulan biaya, karena apabila keunggulan biaya diterapkan perusahaan pada suatu ketika akan merugi. Karyawan karena memiliki keahlian tertentu (karena tidak adanya 4 macam alat ukur) justru rawan terhadap biaya tinggi, karena mereka sewaktu-waktu dapat menuntut kenaikan gaji atau fasilitas tertentu dan sistem produksi dapat terhenti hanya karena salah seorang karyawan tidak masuk kerja. Tenaga ahli ini juga merupakan titik rawan yang dapat diserang oleh pesaing yaitu dengan melalui pembajakan dengan iming-iming upah yang lebih tinggi. Keunggulan biaya dapat dicapai secara terbatas namun hanya berlaku 
dalam jangka pendek yaitu melalui peningkatan kualitas dan standar produk, dengan cara menambah 4 macam alat ukur dan karyawan dikontrak minimal untuk satu musim giling di mana syarat-syarat kontrak di atur secara jelas dan tegas serta disepakati oleh kedua belah pihak. Keunggulan biaya dapat dicapai secara lebih luas melalui upaya lebih meningkatkan kualitas dan standar produk serta produktivitas dengan cara mengganti dominasi tenaga kerja manusia dengan mesin yang berteknologi lebih maju. Penggunaan teknologi yang lebih maju, kemungkinan memerlukan investasi yang mahal sehingga penerapan kebijakan keunggulan biaya dalam jangka pendek dapat berakibat menurunnya profit margin, tetapi dalam jangka panjang diperkirakan dapat diperoleh profit margin yang melebihi perolehan tertinggi sebelumnya. Prakiraan ini didasarkan suatu perhitungan bahwa perusahaan tidak harus berpikir tentang menaikkan gaji karyawan atau tuntutan fasilitas dari karyawan. Pengurangan jumlah tenaga kerja dapat berarti pula mengurangi kerawanan dari serangan pesaing yang memanfaatkan tenaga kerja. Oleh karena itu, agar keunggulan biaya dapat terwujud, maka pilihan kebijakan ini perlu diikuti dengan perluasan pasar (ekonomi skala) terutama pasar ekspor, penetapan harga premium dan promosi serta penentuan saluran distribusi yang tepat.

Aktivitas nilai logistik keluar, misalnya penggudangan produk jadi, pemrosesan pesanan, pengaturan jadwal dan pengiriman sangat mendukung kebijakan keunggulan biaya. Produsen tidak perlu menyiapkan gudang yang luas dan melakukan berbagai kegiatan penggudangan berikut resiko-resikonya, sebab pada setiap hari, setiap kegiatan memproduksi sudah selesai, seluruh produk langsung diambil oleh atau diantar ke konsumen. Dengan konsumen yang sudah pasti dan telah disepakatinya jadwal dan penggunaan sarana angkut, proses pengiriman produk kepada konsumen dapat berjalan secara cepat dan lancar, jadi sangat efisien. Namun, proses ini memiliki kelemahan yang dapat dimanfaatkan oleh pesaing yaitu karena proses ini hanya didasarkan pada saling percaya dan kesepakatan tidak tertulis dan tidak berkekuatan hukum. Untuk mencegah masuknya pesaing, maka kesepakatan ini harus dibuat secara tertulis dan harus berkekuatan hukum.

Program pengembangan dan pelatihan bagi para karyawan IKGMT sangat sedikit, namun melalui proses learning by doing, mereka akhirnya menjadi "ahli" di bidangnya masing-masing. Pada uraian di atas telah dikemukakan bahwa keberadan para karyawan kurang mendukung kebijakan keunggulan biaya dan peluang untuk mendukung ini akan makin berkurang ketika perusahaan dihadapkan pada persaingan yang makin ketat. Dengan wawasan yang sangat terbatas (berijazah SD atau sederajat), karyawan tidak mungkin dituntut untuk mengembangkan kreativitas dan inovatif secara konsisten, tetapi persaingan yang ketat justru mengha- 
ruskan dikembangkannya kreativitas dan inovasi secara konsisten agar perusahaan mampu bersaing. Tuntutan ini justru menjadi semakin kuat ketika perusahaan menetapkan kebijakan keunggulan biaya. Untuk mengatasi masalah ini, penulis mengemukakan tiga alternatif dengan resikonya masing-masing yaitu, pertama, dilakukan kegiatan pengembangan dan pelatihan bagi karyawan yang ada secara terarah dan berkesinambungan dengan tujuan memperluas wawasan mereka sehingga mereka lebih kreatif dan inovatif, meninggalkan sikap nrimo dan menggantinya dengan sikap ingin maju - ingin lebih baik. Namun karena bekal dasar mereka hanya SD, kalaupun mereka mengalami kemajuan dalam hal wawasan, kemajuan itu tentu terbatas dan dalam waktu relatif cepat sudah akan ketinggalan lagi. Di samping itu masih adanya resiko tuntutan kenaikan gaji maupun fasilitas tertentu. Kedua, merekrut karyawan baru tamatan SLTA atau PT, kemudian diberi pelatihan tentang membuat GMT. Mereka ini memiliki wawasan yang lebih luas, daya kreativitas dan inovasinya lebih baik, sehingga lebih memiliki peluang untuk mampu menghadapi persaingan yang makin ketat. Namun, perusahaan tidak akan terbebas dari resiko permintaan gaji yang tinggi dan berbagai fasilitas. Ketiga, mengganti teknologi produksi dengan mesin yang berteknologi lebih maju yang dapat mengurangi sebagain besar peran tenaga kerja manusia. Resikonya adalah bahwa dalam jangka pendek, kemungkinan perolehan profit margin sangat sedikit sebagai akibat posisi biaya perusahaan yang terbebani investasi teknologi, namun dalam jangka panjang, kebijakan keunggulan biaya dapat memberikan profit margin yang lebih baik karena posisi biaya terlepas dari beban kompensasi bagi karyawan yang dari waktu ke waktu terus meningkat.

Kecuali keunggulan biaya, keunggulan bersaing lainnya adalah diferensiasi. Sebuah perusahaan dikatakan mendiferensiasikan diri terhadap pesaingnya apabila perusahaan tersebut dapat memiliki keunikan dalam sesuatu yang dinilai penting oleh pembeli. Seringkali sumber potensial bagi diferensiasi tumbuh dari rantai nilai perusahaan, dimana setiap aktivitas nilai merupakan sumber potensial bagi keunikan. Aktivitas nilai IKGMT yang dibahas meliputi logistik ke dalam, operasi, logistik ke luar, pemasaran dan penjualan, serta pengembangan teknologi. Di samping itu, keunikan perusahaan dalam sebuah aktivitas nilai ditentukan oleh sejumlah penentu pokok yang sejalan dengan penentu biaya seperti telah diuraikan di atas. Beberapa penentu pokok keunikan yang dibahas dalam kasus IKGMT adalah pilihan kebijakan, keterkaitan (dengan rantai nilai yang ada maupun dengan pemasok), pengaturan waktu, pembelajaran dan skala. Pembahasan aktivitas nilai dan penentu pokok keunikan akan dilakukan secara terintegrasi, karena suatu aktivitas nilai dapat terkait dengan lebih baik dari satu penentu pokok keunikan atau sebaliknya, yaitu satu penentu pokok keunikan dapat terkait dengan lebih dari satu aktivitas nilai dan 
dengan demikian akan diperoleh gambaran secara utuh suatu rangkaian masalah yang saling mempengaruhi.

Aktivitas nilai logistik ke dalam, khususnya aktivitas nilai penggudangan, dalam hubungannya dengan penentu pokok diferensiasi yaitu keterkaitan dan pengaturan waktu, berpotensi besar menghadirkan keunikan. Produsen IKGMT dalam rangka mendapatkan tebu dari pemasok, dapat melakukan kerja sama dengan pemasok guna mendapatkan tebu yang kualitasnya baik (masak, segar dan bersih) dengan pengiriman yang tepat waktu. Dengan tebu yang berkualitas baik dan pengiriman yang tepat waktu, produsen IKGMT dapat mendiferensiasikan produk sesuai dengan kebutuhan pasar serta produksi yang lancar dan penyerahan produk kepada pelanggan secara tepat waktu. Pengiriman bahan baku secara tepat waktu ini sangat penting diperhatikan agar ketika diproses, kualitas bahan baku tetap dalam kondisi baik. Namun demikian, aktivitas penebangan tebu sebelum tebu dikirim ke IKGMT juga harus dilakukan secara tepat waktu pula (dengan ketentuan bahwa dalam 36 jam setelah ditebang, tebu harus sudah digiling). Dalam pembahasan di depan, aktivitas nilai ini jelas mendukung konsep keunggulan biaya, karena terjadi efisiensi terutama dalam aktivitas penggudangan. Guna mencegah masuknya pesaing agar diferensiasi ini dapat bertahan lama, maka perlu dilakukan kontrak kerja sama dengan pemasok dan produsen harus berani memberikan harga bahan baku yang lebih tinggi daripada harga pasar (seperti yang dilakukan oleh $\mathrm{H}$. Ruba'i).

Kebijakan H. Ruba'i mendapatkan bahan baku dengan kualitas yang baik belum diikuti dengan kebijakan pilihan teknologi produksi yang lebih baik, sehingga di pasar domestik ciri-ciri dan kinerja produknya tidak terlalu berbeda dengan produk dari perusahaan lain, sedangkan di pasar ekspor hanya unggul dari aspek rasa yang sangat manis dan aroma GMT yang spesifik, namun kalah pada aspek daya tahan dan tampilan produk. Rasa sangat manis dan aroma yang spesifik, merupakan keunikan yang berasal dari berkah alam tropis yang membedakannya dengan produk GMT dari negara-negara sub tropis. Namun terbentuknya keunikan aroma GMT juga didukung oleh penggunaan bahan bakar dari ampas tebu, sehinga aroma tebu pada GMT makin tajam. Aktivitas nilai pengembangan teknologi produksi guna memproses bahan baku yang baik, akan mampu mewujudkan pilihan kebijakan pembuatan produk yang unik yaitu yang memiliki ciri-ciri dan kinerja yang berbeda-beda sesuai dengan kebutuhan pasar. Misalnya, untuk memenuhi kebutuhan pasar, dibuat produk yang berwarna kemerah-merahan untuk memenuhi kebutuhan pasar industri makanan dan minuman, dan yang berwarna kekuning-kuningan untuk industri perhotelan dan rumah tangga. Jadi pada dasarnya, dengan digunakannya teknologi produksi yang lebih maju, peluang pengembangan kon- 
sep diferensiasi makin terbuka, karena lebih memungkinkan dikembangkannya lini produk, produk dengan kualitas yang baik, standar dan konsisten serta produktivitas yang makin meningkat. Dengan pengembangan teknologi produksi dengan segala manfaat yang kemungkinan dapat diperoleh, skala ekonomi memungkinkan dan perlu dikembangkan dengan melalui perluasan pasar, terutama pasar ekspor, dan disertai dengan kecukupan dan kelancaran pasokan bahan baku, didukung oleh proses produksi yang sistematis karena menggunakan teknologi produksi yang lebih maju, dapat menjamin kelancaran proses produksi dan tersedia produk untuk memenuhi pesanan pelanggan. Proses penyerahan produk diatur berdasarkan jadwal yang telah disepakati, pada umumnya setiap sore atau malam hari setelah proses produksi selesai, tetapi khusus untuk H. Ruba'i menyerahkan produknya setiap 10 (sepuluh) hari sekali (ekspor ke Jepang). Keunikan aktivitas penyerahan atau pengiriman produk di pasar lokal daya tahannya menjadi hilang ketika semua produsen GMT telah melakukan hal yang sama, tetapi untuk pasar ekspor, peluang menjadi unik dan berdaya tahan lama cukup terbuka yaitu dengan cara mengadakan kerja sama dengan perantara transportasi domestik maupun antar negara.

Seperti dikatakan oleh Porter (1994) bahwa diferensiasi biasanya membutuhkan biaya tinggi, perusahaan seringkali harus mengeluarkan biaya untuk menjadi unik, karena untuk mencapai keunikan perusahaan harus melakukan sejumlah aktivitas nilai secara lebih baik daripada para pesaingnya. Dalam kasus IKGMT ini biaya-biaya yang perlu dikeluarkan perusahaan adalah untuk melakukan aktivitas nilai seperti logistik ke dalam keterkaitannya dengan pemasok yaitu pengadaan persediaan bahan baku, pengembangan teknologi produksi, perluasan pasar dan promosi. Namun perusahaan akan mendapatkan keuntungan dari efisiensi-efisiensi yang dapat dilakukan yaitu pada aktivitas penggudangan bahan baku dan produk jadi, penghematan gaji karyawan, berkurangnya resiko administratif lainnya yang memerlukan biaya, serta meningkatnya kualitas dan standar produk, produktivitas, dan makin besarnya peluang untuk mendapatkan profit margin yang lebih tinggi. Oleh karena itu, perusahaan harus membandingkan antara biaya menjadi unik dengan nilai pembeli.

\section{KESIMPULAN DAN SARAN}

Berbicara tentang pemasaran, yang pada ujung-ujungnya adalah tercapainya tujuan perusahaan yaitu sasaran penjualan dan laba tertentu, perlu diawali dari jauh ke belakang yaitu mulai dengan filosofi pemasaran yang dianut sampai pada tindakan-tindakan strategis dan teknis operasional di lapangan guna mencapai sasaran-sasaran tersebut. Filosofi pemasaran berwawasan pelanggan maksudnya adalah bagaimana agar pelang- 
gan menjadi puas (Kotler dan Amstrong, 1997), yang menurut Agung (2002) kepuasan ini merupakan unsur utama pembentuk loyalitas dan loyalitas inilah yang bertanggung jawab terhadap profitabilitas, namun Goni (2001) berpendapat bahwa penjualan dan laba dipengaruhi oleh implementasi marketing mix serta strategi segmenting dan positioning. Di samping faktor-faktor di atas, masih banyak lagi faktor lain yang dapat mempengaruhi volume penjualan dan laba, misalnya pesaing dan persaingan. Guna menambah wawasan, makalah ini membahas bagaimana membangun keunggulan bersaing guna memperoleh dan meningkatkan volume penjualan dan laba, dengan kasus IKGMT di Kabupaten Kediri

GMT dari Kabupaten Kediri yang diwakili oleh produk H. Ruba'i mampu memasuki pasar ekspor, khususnya ke Jepang, kaena memiliki keunggulan bersaing keunikan produk yaitu rasanya yang manis dan aromanya yang spesifik. Diferensiasi produk ini lebih disebabkan oleh karunia Tuhan Y.M.E karena tebu di daerah tropis berpeluang menjadi lebih manis daripada tebu yang tumbuh di daerah sub tropis. Namun untuk aroma yang spesifik di samping karena faktor alami juga karena pengapian yang menggunakan ampas tebu mengakibatkan aroma tebu makin tajam.

Namun IKGMT memiliki kelemahan yaitu kurang efisien dan produk GMT kurang baik serta tidak standar misalnya dalam hal rasa, warna dan daya tahan. Beberapa aktivias nilai masih memiliki peluang untuk dikembangkan agar IKGMT memiliki keunggulan bersaing baik dari aspek keunggulan biaya maupun diferensiasi, misalnya untuk mendapatkan bahan baku yang berkualitas baik, sinkronisasi jadwal tebang, pengiriman tebu dan persediaan bahan baku maupun penggudangan, kebijakan pilihan teknologi produksi, perluasan pasar terutama pasar ekspor, promosi, penyerahan produk dan lain-lain. Walaupun IKGMT memiliki peluang untuk unggul dalam bersaing, tetapi perlu dilakukan pengkajian secara seksama terhadap pilihan aspek-aspek keunggulan bersaing agar pilihan itu dapat mendukung konsep pemasaran yang dikembangkan oleh perusahaan.

Beberapa hal yang perlu disarankan adalah adanya kerja sama yang mengikat dan berkekuatan hukum antara produsen dengan pemasok, produsen dengan konsumen industri dan antara perusahaan dengan karyawan. Produsen harus berani memberikan harga tinggi untuk bahan baku, menggunakan teknologi produksi yang lebih maju dengan meminimalisasi serendah mungkin dominasi peran tenaga kerja manusia, IKGMT perlu membentuk sebuah organisasi guna memasuki pasar ekspor atau guna meningkatkan daya tawar terhadap pasar domestik baik pasar bisnis maupun pasar industri. 


\section{DAFTAR PUSTAKA}

Agung, Yuliana, 2001, Kepuasan dan Profitabilitas, Jakarta: Majalah Informasi \& Peluang Bisnis SWA Sembada, No. 18/XVII/6-19 Septembr 2001

, (1999-2004), Garis-Garis Besar Haluan Negara Republik Indonesia, Jakarta : CV. Tamita Utama

Goni, Roy, 2001, Benarkah Giv atau Hero Gagal ?, Jakarta : Majalah Informasi dan Peluang Bisnis SWA Sembada, No. 18/XVII/6-19 September 2001

Hafsah, Mohammad Jafar, 2002, Bisnis Gula di Indonesia, Jakarta : Pustaka Sinar Harapan

Kotler, Philip dan Amstrong, Gary, 1997, Dasar-Dasar Pemasaran, alih bahasa Alexander Sindoro, Jakarta : Prehalindo

Porter, Michael E, 1994, Keungulan Bersaing, alih bahasa Agus Dharma et.al, Jakarta : Erlangga

Purnomo, Edi, 1997, Pembuatan Gula Merah Tebu yang Baik dan Efisien, Pasuruan : P3GI

Suparyadi, 2003, Pengaruh Faktor-Faktor Lingkungan Makro Ekstern, Lingkungan Mikro Ekstern, Bauran Pemasaran dan Lingkungan Non Pemasaran Intern Terhadap Kinerja Pemasaran Dalam Rangka Pemberdayaan Industri Kecil Gula Merah di Kabupaten Kediri, Disertasi, Universitas 17 Agustus 1945 Surabaya

Supriyadi, Achmad, 1992, Rendeman Tebu: Liku-Liku Permasalahannya, Yogyakarta : Kanisius 